MAKALAH

\title{
PENGARUH MODERANISASI DARI SEJARAH EROPA
}

"Disusun dalam memenuhi salah satu tugas kelompok pada mata kuliah Sejarah Eropa (AKBK1206)"

\section{Dosen Pengampu:}

Dr. Mohammad Zaenal Arifin Anis, M.Hum. Mansyur, S.Pd.,M.Hum.

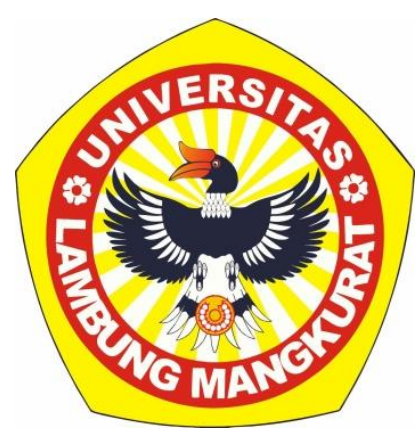

Disusun Oleh:

Kelompok V

\author{
Halda Nor Halisa ～（2010111220018) \\ Siti Mawaddah ～(2010111120011) \\ Wahdah $\quad$ (2010111120013) \\ Kelas : A1 \\ Mata Kuliah: Sejarah Eropa
}

\section{PROGRAM STUDI PENDIDIKAN SEJARAH JURUSAN PENDIDIKAN ILMU PENGETAHUAN SOSIAL FAKULTAS KEGURUAN DAN ILMU PENDIDIKAN UNIVERSITAS LAMBUNG MANGKURAT BANJARMASIN}




\section{KATA PENGANTAR}

Segala puji dan syukur hanya milik Allah SWT, shalawat dan salam selalu tercurahkan kepada Rasulullah SAW. Berkat limpahan rahmat dan karunia-Nya, penulis mampu menyelesaikan tugas makalah ini guna memenuhi tugas Mata Kuliah Sejarah Eropa.

Penulis mengucapkan terima kasih kepada dosen pengampu Dr. Mohammad Zaenal Arifin Anis, M.Hum. dan Mansyur, S.Pd.,M.Hum. yang telah memberikan tugas ini sehingga dapat menambah pengetahuan dan wawasan sesuai dengan bidang studi yang penulis tekuni.

Makalah ini dapat terselesaikan tidak lepas karena bantuan dan dukungan dari berbagai pihak yang tulus dan sabar memberikan sumbangan baik berupa ide, materi pembahasan dan juga bantuan lainnya yang tidak dapat dijelaskan satu persatu.

Makalah ini disusun agar pembaca dapat memperluas wawasan mengenai "Pengaruh dari Modernisasi dari Sejarah Eropa" yang penulis sajikan berdasarkan dari berbagai sumber informasi seperti artikel, jurnal, buku khususnya karya ilmiah dari Dr. Mohammad Zaenal Arifin Anis, M.Hum. dkk yang berjudul DARI DISTRIK KE KOTA KECAMATAN Menyusuri Jejak Kota Satui Dalam Lintasan Sejarah yang diterbitkan pada tahun 2013 yang memiliki 136 halaman dan referensi lainya. Semoga makalah ini dapat memberikan wawasan yang lebih luas dan menjadi sumbangan pemikiran kepada pembaca.

Penulis menyadari bahwa makalah ini masih banyak kekurangan dan jauh dari sempurna. Untuk itu, kepada dosen pengampu penulis meminta masukannya demi perbaikan pembuatan makalah penulis di masa yang akan datang dan mengharapkan kritik dan saran dari para pembaca.

Banjarmasin, 7 Mei 2021

Penulis 


\section{DAFTAR ISI}

Halaman

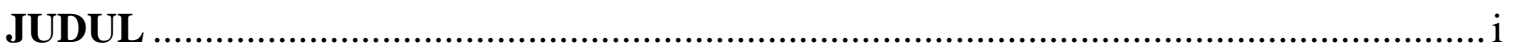

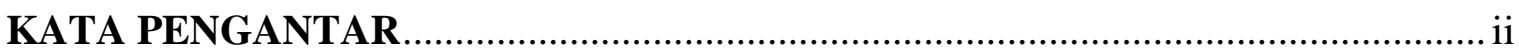

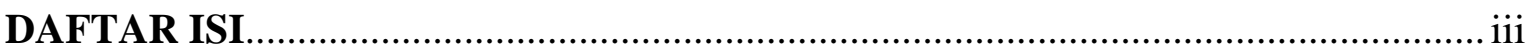

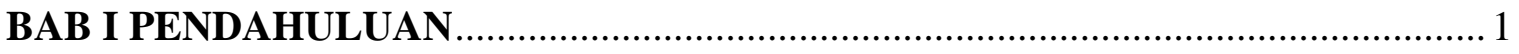

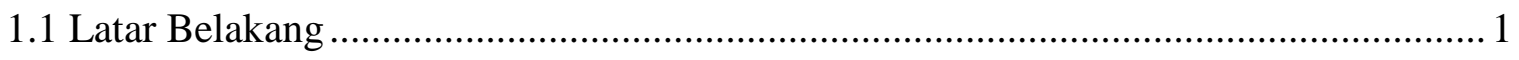

1.2 Rumusan Masalah ........................................................................................... 2

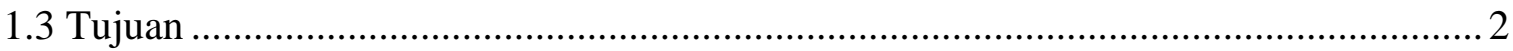

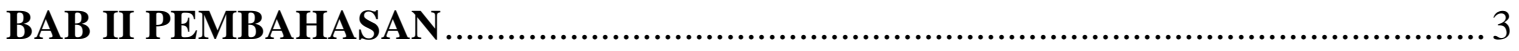

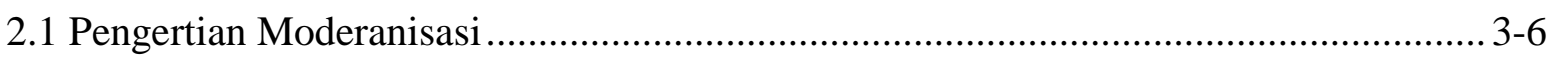

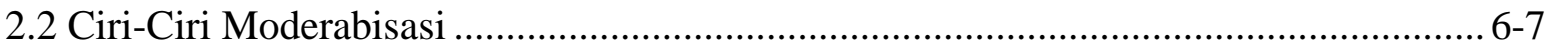

2.3 Sejarah Perkembangan Moderanisasi ................................................................ $7-11$

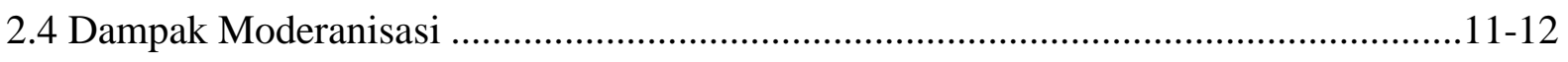

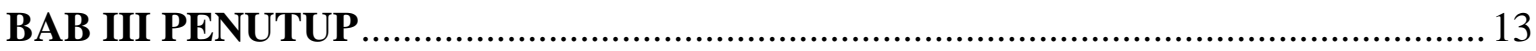

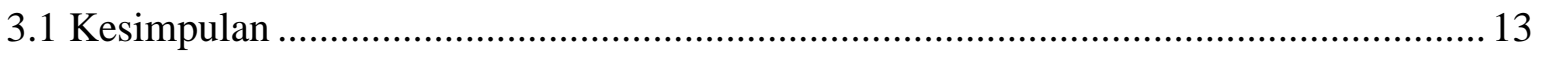

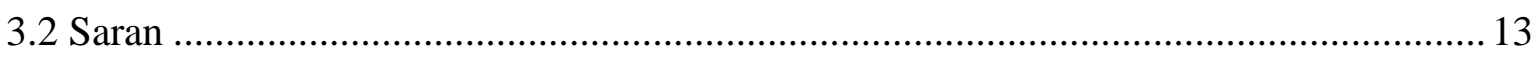

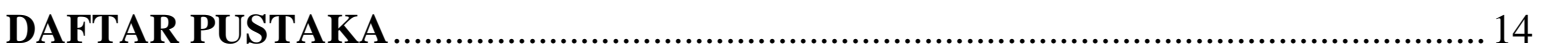




\section{BAB I}

\section{PENDAHULUAN}

\subsection{Latar Belakang}

Modernisasi merupakan proses menuju masyarakat yang modern, dalam prosesnya melibatkan perubahan masyarakat tradisional menuju masyarakat yang modern. Modernisasi ditandai dengan adanya perkembangan ilmu pengetahuan yang terdiri dari teori, praktik, prosedur, peralatan dan teknik yang digunakan hal ini disebut teknologi. Adanya modernisasi dapat mempengaruhi pergaulan bebas baik di perkotaan maupun perkotaan, Disamping hal tersebut modernisasi juga sangat membantu masyarakat dalam menjalani aktivitasnya karena adanya perkembangan teknologi industri yang sudah modern dan sudah berkembang pesat memudahkan masyarakat untuk mengakses informasi dan menggunakan teknologi dengan mudah. Dari latar belakang tersebut penulis dalam menyusun makalah ini mengangkat tema tentang modernisasi agar para pembaca dalam menghadapi modernisasi dapat menyikapi secara bijak dan dapat bertambah wawasannya mengenai sejarah perkembangan modernisasi yang berkaitan erat dengan sejarah eropa.

Dari hal tersebut penulis sangat tertarik mengangkat makalah yang "Pengaruh Modernisasi dari Sejarah Eropa" yang dikaitkan dengan karya ilmiah berupa buku dari Dr. Mohammad Zaenal Arifin Anis, M.Hum. dkk yang berjudul DARI DISTRIK KE KOTA KECAMATAN Menyusuri Jejak Kota Satui Dalam Lintasan Sejarah yang diterbitkan pada tahun 2013 yang memiliki 136 halaman yang pembahasannya lebih dikhususkan pada BAB II tentang Rujukan dan Teori-Teori Sejarah Perkotaan pada halaman 11-49. 


\subsection{Rumusan Masalah}

1. Apa yang dimaksud dengan Moderanisasi?

2. Apa ciri-ciri Moderanisasi ?

3. Bagaimana sejarah perkembangan Moderanisasi?

4. Bagaimana dampak Moderanisasi bagi dunia khususnya di Indonesia?

\subsection{Tujuan}

Sesuai dengan permasalahan yang dikemukakan di atas, maka makalah ini bertujuan secara khusus untuk:

1. Mengetahui dan memahami pengertian dari Moderanisasi ?

2. Mengetahui ciri-ciri dari Moderanisasi?

3. Mengetahui dan memahami sejarah perkembangan Moderanisasi?

4. Mengetahui dampak Moderanisasi bagi dunia khususnya di Indonesia? 


\section{BAB II}

\section{PEMBAHASAN}

\subsection{Pengertian Modernisasi}

Menurut Koentjraningrat menyatakan modernisasi sebagai usaha untuk hidup sesuai dengan zaman dan konstelasi dunia sekarang. Menurut Ogburn dan Nimkoff modernisasi harus mengarahkan masyarakat agar dapat memproyeksikan diri ke masa depan yang nyata dan bukan angan-angan semu, sedangkan menurut Soekanto Modernisasi mencakup proses yang sangat luas. Kadang-kadang batasnya tidak dapat ditetapkan secara mutlak. Mungkin di suatu daerah tertentu, modernisasi mencakup pemberantasan buta huruf, di lain tempat proses tadi mencakup usaha usaha penyemprotan rawa-rawa dengan DDT untuk mengurangi sumber-sumber penyakit malaria, atau mungkin diartikan sebagai usaha membangun pusatpusat tenaga listrik. Gambaran serupa dikemukakan Wilbert Moore yang mengatakan bahwa modernisasi merupakan transformasi total masyarakat tradisional atau pra-moderen ke tipe masyarakat teknologi dan organisasi sosial yang menyerupai kemajuan dunia barat yang ekonominya makmur dan situasi politik stabil. Modernisasi dalam ilmu sosial merujuk pada sebuah bentuk transformasi dari keadaan yang kurang maju atau kurang berkembang ke arah yang lebih baik dengan harapan akan tercapai kehidupan yang lebih maju, berkembang, dan makmur. Modernisasi tidak sekedar menyangkut aspek yang meteriil saja, melainkan juga aspek immaterial seperti pola pikir, tingkah laku, dan lain sebagainya.

Pada dasarnya pengertian modernisasi mencakup suatu transformasi total kehidupan bersama yang tradisional atau pra modern dalam arti teknologi serta organisasi sosial ke arah pola-pola ekonomis dan politis yang menjadi ciri negara-negara Barat yang stabil. Modernisasi merupakan suatu bentuk perubahan sosial. Biasanya perubahan sosial yang terarah yang didasarkan pada perencanaan. Modernisisasi merupakan suatu persoalan yang harus dihadapi masyarakat yang bersangkutan karena prosesnya meliputi bidang-bidang yang sangat luas menyangkut proses disorganisasi, problema-problema sosial, konflik antara kelompok dan lain sebagainya. Konsep modernisasi dalam arti khusus yang disepakati teoritisi modernisasi di tahun 50an dan tahun 60an, didefinisikan dalam tiga cara yaitu historis, relatif, dan analisis. Menurut definisi historis modernisasi sama dengan westernisasi atau Amerikanisasi. Modernisasi dilihat sebagai gerakan menuju ciri-ciri masyarakat yang dijadikan model. 
Eisentadt mengatakan secara historis modernisasi adalah proses perubahan menuju proses sistem sosial, ekonomi, dan politik yang telah maju di Eropa Barat dan Amerika Utara dari abad ke-17 hingga ke-19 dan kemudian menyebar ke Negara Eropa lain dari abad ke-19 sampai abad ke-20 ke Negara Amerika Selatan, Asia, Afrika. Menurut pengertian relatif, modernisasi berarti upaya yang bertujuan untuk menyamai standar yang dianggap modern baik oleh rakyat banyak maupun oleh elite penguasa. Tetapi standar ini berbeda-beda, tergantung pada sumber atau pusat rujukan tempat asal prestasi yang dianggap modern. Menurut Tiryakian, pusat modernitas bergeser mulai dari bibitnya yaitu masyarakat Yunani dan Israel melalui Romawi, Eropa Utara, dan Barat Laut di abad pertengahan, kawasan pengaruh Amerika Serikat, dan kini bergeser ke Timur Jauh, pinggiran Pasifik, atau dimasa mendatang mungkin kembali ke Eropa. Sedangkan definisi untuk analisis berciri lebih khusus yakni melukiskan dimensi masyarakat modern dengan maksud untuk ditanamkan dalam masyarakat tradisional atau masyarakat pra-modern. Makna modernisasi paling khusus hanya mengacu pada masyarakat terbelakang atau tertinggal dan melukiskan upaya mereka untuk mengejar ketertinggalan dari masyarakat paling maju yang hidup berdampingan dengan mereka pada periode historis yang sama dalam masyarakat global. Dengan demikian, modernisasi melukiskan gerakan dari pinggiran menuju inti masyarakat modern.

Bagi Ferdinand Toenise modernisasi berarti hilangnya komunitas yang ia sebut dengan gemeinschaft. Dalam gemeinschaft didasari oleh ikatan personal. Bentuk gemeinschaft dapat dijumpai dalam keluarga, kelompok kekerabatan, rukun tetangga dan sebagainya. Penetrasi industrialisasi dalam gemeinschaft yang menekankan fakta, eficiency, specialization dan cost effectiveness telah menyebabkan hubungan kekerabatan di ganti dengan hubungan yang bersifat impersonal. Hubungan impersonal ini tidak berakar dalam dan solidaritas sosialnya sangat lemah. Komunitas impersonal ini disebutnya dengan gesellschaft. Emile Durkheim melihat modernisasi dalam konteks hilangnya solidaritas mekanik. Solidaritas mekanik didasari oleh adanya kesadaran kolektif yang kuat yang ratarata ada masyarakat yang sama. Dalam solidaritas mekanik tingkat solidaritasnya sangat tinggi. Homogenitas ini dapat kita lihat dalam kepercayaan dan sentimen-sentimen moral dan agama lainnya. Pembagian kerja dalam solidaritas mekanik sangat minim. Namun ketika terjadi pembagian kerja, yang merupakan salah satu karakteristik dari modernisasi, solidaritas mekanik ini diganti oleh solidaritas organik. Dalam solidaritas organik tingkat ketergantungan sangat tinggi. Ketergantungan ini disebabkan oleh pembagian kerja yang 
berdasarkan spesialisasi. Kesadaran kelompok juga sangat rendah dalam solidaritas organik. Individu lebih otonom.

Karl Marx melihat bahwa masyarakat modern sinonim dengan masyarakat kapitalis dan sistem ekonomi yang dihasilkan oleh perjuangan kelas yang menjadi akhir dari era feodal sejarah masyarakat Eropa. Marx tidak menolak munculnya modernitas yang meliputi hilangnya komunitas berskala kecil atau berkembangnya pembagian kerja atau munculnya rasionalisasi pandangan tentang dunia. Karl Marx menekankan bahwa ketiga faktor di atas mempercepat bertumbuhnya kapitalisme. Kapitalisme menarik populasi dari desa dan kotakota kecil ke sistem pasar yang berpusat di kota. Spesialisasi merupakan dasar dari pembagian kerja dan rasionalisasi mengekspresikan masyarakat modern yang menekankan profit yang besar. Kebanyakan masyarakat di dunia ini terkait pada jaringan modernisasi, baik yang baru memasukinya, maupun yang sedang meneruskan tradisi modernisasi. Modernisasi sejatinya meliputi bidang-bidang yang sangat kompleks. Mau tidak mau masyarakat harus menghadapi modernisasi. Modernisasi pada awal-awalnya akan mengkibatkan disorganisasi dalam masyarakat. Terlebih lagi jika sudah menyangkut nilai-nilai dan norma-norma masyarakat. Modernisasi bersifat preventif dan konstruktif, memproyeksikan kecenderungan yang ada dalam masyarakat di masa mendatang.

Adapun syarat-syarat suatu modernisasi adalah sebagai berikut:

1. Cara berpikir yang ilmiah (scientific thinking) yang melembaga bagi para penguasa maupun masyarakat.

2. Sistem admiinistrasi negara yang baik dan benar-benar beroreantasi untuk mewujudkan birokrasi.

3. Adanya sistem pengumpulan data yang baik, teratur, dan terpusat pada suatu badan dan lembaga tertentu.

4. Penciptaan iklim yang favorable dari masyarakat terhadap modernisasi dengan cara penggunaan alat-alat komunikasi massa yang dilakukan dengan tahap demi tahap karena menyankut dengan sistem kepercayaan masyarakat (belief system).

5. Tingkat organisasi yang tinggi, yang mana di satu pihak bersiifat disiplin dan di pihak lain mengakibatkan pengurangan kemerdekaan.

6. Sentralisasi wewenang dalam pelaksanaan perencanaan sosial (social planning), ketika tidak dilakukan hal ini, perencanaan akan terpengaruh akan kekuatan-kekuatan 
dari kepentingan-kepentingan yang ingin mengubah perencanaan sosial tersebut demi kepentingan suatu golongan tertentu dalam masyarakat. ${ }^{1}$

\subsection{Ciri-Ciri Modernisasi}

- Dalam masyarakat modern, tindakan sosial diambil berdasarkan pilihan, bukan berdasarkan kebiasaan atau tradisi.

- Masyarakat modern selalu mengalami perubahan-perubahan secara cepat karena kualitas masalah yang dihadapi oleh masyarakat modern cenderung kompleks sehingga masyarakat modern cenderung menyesuaikan diri.

- Kompleksitas permasalahan yang di hadapi masyarakat modern memunculkan adanya spesialisasi di segala bidang.

- Sistem perekonomian masyarakat modern berorientasi pada efisiensi dan kemampuan untuk memelihara pertumbuhannya, sedangkan mekanismenya bertumpu pada pasar.

- Dalam masyarakat modern, penghargaan lebih besar di berikan kepada individu berdasarkan kemampuan intelektualitasnya yang mendatangkan banyak prestasi.

- Dalam masyarakat modern hubungan antar individu, telah jauh berkurang, masyarakat cenderung induvidualis namun lebih objektif dalam memandang individu lainnya.

- Manusia modern selalu ingin mendapat pengakuan sebagai individu, selain sebagai anggota masyarakat.

- Manusia modern senantiasa berupaya untuk terus maju, tidak statis dan berusaha menampilkan serta mencari yang terbaik sehingga masyarakat modern sangat menjunjung tinggi profesionalitas.

- Pada umumnya, masyarakat modern mampu membimbing dirinya sendiri. Mampu menetapkan pilihan-pilihan dan mengambil keputusan sendiri untuk menghadapi perubahan-perubahan.

- Struktur sosial masyarakat modern bersifat terbuka dan sukarela.

- Mobilitas sosial masyarakat modern sangat tinggi, baik ke atas maupun ke bawah sehingga siapapun bisa berpindah-pindah kelas, atas atau bawah kapan saja bergantung pada potensinya.

${ }^{1}$ Soerjono, Sekanto, dan Budi Sulistiyowati. 2015. SOSIOLOGI SUATU PENGANTAR. PT RajaGrafindo Persada Jakarta. Hal 304 
- Masyarakat modern menjunjung tinggi HAM dalam memperoleh keadilan, kesempatan, hak serta keajaiban yang sama.

- Tingkat perekonomian dan pendidikan masyarakat modern umumnya merata dan berada pada garis menengah.

\subsection{Sejarah Perkembangan Modernisasi}

Teori modernisasi lahir sebagai produk sejarah atas peristiwa penting setelah masa perang dunia II, yaitu munculnya Amerika Serikat sebagai kekuatan dominan di dunia Lahirnya teori modernisasi ini, ditandai dengan beberapa momentum penting. Pertama, terjadinya revolusi intelektual di setiap negara untuk melakukan respon terhadap Perang Dunia II. Banyak pihak yang meyakini bahwa teori ini sebagai pintu masuk menuju perubahan. Kedua, terjadinya perang dingin antara negara komunis di bawah pimpinan negara sosialis Uni Soviet (USSR) yang berideologi sosialis dan Amerika Serikat yang berideologi kapitalis. Dominasi yang ditunjukkan oleh kedua negara tersebut bermuara pada ekspansi wilayah di berbagai negara berkembang untuk menerapkan ideologi mereka. dua teori besar yang mempengaruhinya, yaitu teori evolusi dan teori fungsional.

Teori modernisasi asumsinya itu berasal dari teori evolusi. Menurut teori evolusi, perubahan sosial pada dasarnya merupakan gerakan yang searah, linear, dan perlahan-lahan yang membawa masyarakat berubah dari tahapan primitif ke tahapan yang lebih maju, dan membuat berbagai masyarakat memiliki bentuk struktur yang serupa. Jika modernisasi dilihat berdasarkan atas teori fungsional, teori modernisasi mengandung asumsi-asumsi bahwa modernisasi merupakan proses sistematik, transformasi, dan terus-menerus. Yang pertama sebagai proses sistematik, modernisasi melibatkan perubahan pada segala aspek tingkah laku sosial, yang termasuk didalamnya berupa industrialisasi, urbanisasi, diferensiasi, sekularisasi, dan sentralisasi. Hal ini menjadikan modernisasi sebagai sebuah bentuk yang teratur dibandingkan dengan sebuah proses yang tidak beraturan. Yang kedua sebagai proses transformasi, modernisasi merupakan proses yang membentuk dari sebuah kondisi tradisional menjadi modern dalam segala bentuk aspek sosial budaya. Kemudian yang ketiga sebagai proses terus-menerus modernisasi melibatkan perubahan sosial yang terus-menerus dalam sistem sosial. Sekali terjadi perubahan sosial pada satu aspek kehidupan, akan membawa pengaruh sosial pada aspek lain. 
Porda, H., Anis, M., Mansyur, M., \& HERI, S. (2013). DARI DISTRIK KE KOTA KECAMATAN Menyusuri Jejak Kota Satui Dalam Lintasan Sejarah.

Buku ini merupakan hasil penelitian yang membahas tentang penyusuran jejak Kota Satui dalam lintas sejarah yang mana fokus pembahasan masalah pada buku ini meliputi bagaimana perkembangan Wilayah Satui pada abad ke-19 dan abad ke-20 dan bagaimana fakta-fakta sejarah yang mendukung penentuan Hari Jadi Kecamatan Satui. Dari buku ini penulis dapat kaitkan adanya pengaruh modernisasi pada Konteks RUJUKAN DAN TEORITEORI SEJARAH PERKOTAAN yang dipaparkan pada BAB II dari halaman 11 sampai halaman 49.

\section{Kajian Modernisasi dalam Konteks RUJUKAN DAN TEORI-TEORI SEJARAH PERKOTAAN}

\section{Perkembangan Kota di Indonesia dalam Modernisasi}

\section{a. Kota-Kota Tradisional}

Mencermati perkembangan kota-kota menurut pendapat Djoko Suryo dapat dibedakan atas tiga fase perkembangan, yaitu periode awal/kuna/lama, kolonial dan modern. Tipe kotanya dapat dibedakan antara tipe kota pedalaman atau kota agraris dan kota pantai atau kota perdagangan. Karekteristik kota-kota itu dapat dicermati melaluipersfektif evolusioner. Dalam konteks ini perkembangan kota-kota di Indonesia dapat dikelompokkan dalam tiga kategori, yaitu:

1) kota tradisional (kota-kota pra kolonial)

2) kota kolonial

3) kota pascakolonial.

Munculnya kota tradisional, hemat Sjoberg bertautan erat dengan hadirnya golongan literati (pujangga, sastrawan dan kaum agama). Pandangan ini mengisyaratkan, bahwa ciri sebuah kota secara esensi munculnya pembagian kerja pada tipe-tipe masyarakat yakni the folk atau preliterate society, the feudal (pre-industrial civilized atau literate preindustrial society), dan the industrial urban society (Porda, H dkk. 2013 : 20). Dengan demikian bahwa munculnya kota-kota di Indonesia diawali dengan muncul kerajaan Sriwijaya di Palembang yang mana terdapat kota kota maritim yang berbasis ekonomi perdagangan. 


\section{Kota Tradisional Banjarmasin pada abad ke-19}

Dituliskan Pada tahun 1400-1700. Umumnya mereka tinggal di kota-kota pelabuhan dan mampu menciptakan tradisi di kota-kota lama Indonesia Kelak kota-kota selalu ditandai dengan kehadiran pasar, masjid dan pemerintahan. Hal ini dapat dikatakan, bahwa kota bukan saja sebagai pusat politik dan kebudayaan bagi masyarakatnya, tetaapi juga berfungsi sebagai pusat-pusat magis kerajaan itu sendiri, atau oleh Gertz disebut sebagai doctrineoftheexemplary (Porda, H dkk. 2013 : 23). Pada periode 1400-1700, kota-kota di Nusantara berfungsi sebagai wadah dalam dinamika kebudayaan.

\section{b. Kota Kolonial}

Dalam catatan sejarah, orang-orang Eropa yaitu Portugis dan Belanda mendarat di kota-kota tradisional yang sudah maju dan terletak di pantai. Dalam artian, bahwa mereka mendarat di kota-kota tradisional yang sudah ada kekuasaan formal, yaitu kerajaan-kerajaan pesisir. Dalam konteks ini, kota yang dibangun oleh pemerintah kolonial adalah Batavia, yaitu pada tahun 1619.

Ciri-ciri kota yang dibangun oleh pemerintah kolonial Belanda pada awal abad ke-17, mengikuti gaya bangunan di Eropa yang memiliki empat musin dengan mengimitasi ke kawasan tropis.

\section{Kota Batavia pada Abad ke-18}

Hemat Djoko Suryo, kota-kota kolonial kelak menjadi pusat modernisasi, pusat birokrasi, pemerintah, segreragasi penduduk dan spesialisasi mulai berkembang, munculnya budaya indies atau mezzo-culture yang kelas mendasari terbentuknya kota baru Indonesia, lahirnya golongan elite Indonesia baru dan kelak memunculkan kesadaran sejarah dan kesadaran kebangsaan menjadi pusat modernisasi. kesadaran kebangsaan (Porda, H dkk. 2013 :29-30).

Sehingga Kota Indonesia Baru muncul karena adanya peristiwa Proklamasi 17 Agustus 1945 yang merupakan penanda berakhirnya masa kolonialis Belanda di bumi Indonesia. Sehingga terjadi perubahan kebudayaan Indises ke kebudayaan Indonesia dan telah terjadinya perubahan sosial dari masyarakat yang terjajah menjadi masyarakat yang merdeka. Beriringan dengan perubahan sosial itu, telah terjadi pula perubahan beragam 
dimensi kehidupan, baik politik, pendidikan, administrasi pendidikan, ilmu pengetahuan, teknologi, sosial dan kebudayaan akibat pengaruh modernisasi dari sejarah eropa.

. Muncullah Status kotametropolitan tidak hanya diperuntukan untuk kota Jakarta sebagai Ibukota Republik Indonesia tetapi terlihat pada perkembangannya kota-kota besar yang lainnya seperti Surabaya, Semarang, Bandung, Medan dan Makassar juga mempunyai potensi menjadi kotametropolitan. Selain itu, ada juga kota-kota yang mempunyai predikat daerah istimewa, karena keunikan dalam proses sejarah. Misalnya Daerah Istimewa Jakarta, Yogyakarta dan Aceh. Dengan demikian dapat disimpulkan pergeseran era yang dimulai pasca kemerdekaan sampai era reformasi (1950 sampai kekinian) juga diikuti dengan perkembangan kota-kota. Misalnya, dari kota Indies menjadi pusat transformasi budaya perkotaan di Indonesia yang menjadi pusat kebudayaan Indonesia baru pada era kekinian akibat pengaruh sejarah eropa sebagai dampak modernisasi yang diterapkan di Indonesia oleh bangsa-bangsa eropa yang pernah menjajah Indonesia seperti Portugis, Inggris, Prancis, dan Belanda. $^{2}$

\section{A. Faktor-Faktor Penyebab Modernisasi}

- Kontak dengan kebudayaan lain dengan adanya kontak dengan kebudayaan lain maka terjadinya interaksi sosial yang menyebabkan bertumunya kebuadayaan asing dengan kebudayaan sendiri sehingga menghasilkan budaya baru yang dapat memperkaya kebudayaan tersebut.

- Sistem pendidikan formal yang maju dengan adanya sistem pendidikan formal yang maju maka akan melatih pola pikir agar dapat berpikir secara objektif, rasional dan ilmiah sehingga dapat menilai juga menyaring secara baik apakah kebudayaan asing yang masuk dapat bermanfaat bagi masyarakat maupun negara.

- Sikap menghargai hasil karya seseorang dan keinginan-keinginan untuk maju sehingga masyarakat atau pada setiap diri individu memiliki motivasi untuk membuat karya-karya baru yang dapat mendorong modernisasi.

\footnotetext{
${ }^{2}$ Porda, H., Anis, M., Mansyur, M., \& HERI, S. (2013). DARI DISTRIK KE KOTA KECAMATAN
} Menyusuri Jejak Kota Satui Dalam Lintasan Sejarah. hal 31-32 
- Sistem terbuka lapisan masyarakat dengan adanya sistem terbuka lapisan masyarakat maka akan mendorong terjadinya modernisasi di kalangan masyarakat sehingga masyarakat dapat berorientasi ke depan untuk berpikir lebih maju yang menyebabkan terjadinya penemuan baru sesuai tuntutan zaman modern.

\subsection{Dampak Westernisasi bagi Dunia}

\section{A. Dampak Positif dari Modernisasi}

- Bidang Ilmu Pengetahuan dan Teknologi perannya sangat penting saat proses modernisasi. Usaha - usaha yang dilakukan masyarakat Indonesia dalam menata ulang iptek dilakukan melalui pendidikan, baik pendidikan formal maupun pendidikan nonformal. Perkembangan dan kemajuan iptek dapat memacu masyarakat Indonesia untuk menemukan suatu yang baru, serta mendorong timbulnya perubahan dalam berbagai bidang kehidupan di negara Indonesia.

- Pada sektor pertanian Indonesia terhadap modernisasi ditekankan dengan usahausaha melalui intensifikasi, diversifikasi, ekstensifikasi dan verifikasi pertanian untuk menuju swasembada pangan untuk para masyarakat Indonesia.

- Meningkatkan nilai-nilai demokrasi karena mudahnya mengakses informasi, baik dari media cetak maupun media elektronik, maka semakin banyak pula pengetahuan yang didapatkan oleh masyarakat. Dengan demikian sikap kritis sebagai perwujudan kehidupan yang demokratis akan lebih mudah terbentuk.

\section{B. Dampak Negatif dari Modernisasi}

- Kesenjangan sosial ekonomi merupakan kondisi sosial masyarakat yang sebagian berada pada tingkat kesejahteraan dan kemakmuran yang tinggi sementara sebagian berada pada tingkat yang rendah. Adanya kesenjangan sosial ekonomi menunjukan perbedaan tinggi rendahnya kesejahteraan masyarakat.

- Kriminalitas, bentuk kriminalitas atau tindak kejahatan ini dapat berupa pencurian, penjarahan, perampokan, perkosaan, penganiayaan, pembunuhan, korupsi, prostitusi, dan pemerasan. Proses modernisasi berberdampak pada kriminalitas atau kejahatan. Dampak ini timbul dari disorganisasi atau disintegrasi sosial dari kekosongan nilai dan norma. Faktor penyebab kriminalitas antara lain krisis ekonomi, keinginan yang tidak tersalur, tekanan mental, dan dendam. 
- Kenakalan remaja, faktor lingungan berpengaruh terhadap kenakalan remaja. Pada dasarnya yang bertanggung jawab atas masalah kenakalan remaja adalah keluarga karena fungsinyaa setiap keluarga bertanggung jawab dalam mendidik anggota keluarnyanya agar menjadi manusia dewasa yang baik. modernisasi akan membawa dampak negatif bagi anggota masyarakat, mulai dari kanak-kanak hingga dewasa apabila tidak dilakukan penyaringan terhadap budaya-budaya asing yang masuk ke Indonesia. Sehingga kehidupan sosial masyarakat dapat terpengaruh. 


\section{BAB III}

\section{PENUTUP}

\subsection{Kesimpulan}

Modernisasi merupakan proses menuju masyarakat yang modern, dalam prosesnya melibatkan perubahan masyarakat tradisional menuju masyarakat yang modern. Modernisasi ditandai dengan adanya perkembangan ilmu pengetahuan yang terdiri dari teori, praktik, prosedur, peralatan dan teknik yang digunakan hal ini disebut teknologi. Ciri-ciri modernisasi salah satunya dalam masyarakat modern, tindakan sosial diambil berdasarkan pilihan, bukan berdasarkan kebiasaan atau tradisi. Teori modernisasi lahir sebagai produk sejarah yang terjadi di eropa atas peristiwa penting setelah masa perang dunia II, yaitu munculnya Amerika Serikat sebagai kekuatan dominan di dunia. Modernisasi memiliki dampak positif dan negatife salah satunya adanya kemajuan teknologi sehingga memudahkan masyarakat untuk mengakses informasi sedangkan dampak negatifnya dapat memicu terjadinya pergaulan bebas terutama pada kalangan remaja. Dengan demikian dapat dikatakan bahwa sangat berpengaruh pada penerimaan atau penolakan modernisasi, terutama adalah sikap dan nilai, kemampuan menunjukkan manfaat unsur yang baru, dan kesepadanannya dengan unsur-unsur kebudayan yang ada. Ada kemungkinan bahwa modernisasi bertentangan dengan kebudayaan yang ada atau memerlukan pola-pola baru yang belum ada dan unsur-unsur tertentu dari modernisasi menggantikan unsur-unsur yang lama.

\subsection{Saran}

Penulis menyadari bahwa masih jauh dari kata sempurna dalam menyusun makalah yang membahas tentang pengaruh modernisasi dari sejarah eropa yang dikaitkan dengan karya ilmiah berupa buku dari Dr. Mohammad Zaenal Arifin Anis, M.Hum. dkk yang berjudul DARI DISTRIK KE KOTA KECAMATAN Menyusuri Jejak Kota Satui Dalam Lintasan Sejarah yang diterbitkan pada tahun 2013 yang memiliki 136 halaman, ke depannya penulis akan lebih fokus dan detail dalam menjelaskan tentang makalah ini sebagai sumber terpercaya yang tentunya dapat dipertanggung jawabkan. Maka dari itu, penulis meminta saran kepada pembaca berupa kritik yang membangun terhadap penulisan makalah ini. Semoga adanya makalah ini, pembaca dapat mengerti dan memahami tentang 


\section{DAFTAR PUSTAKA}

Hatu, R.A.(2013). Sosiologi Pembangunan.

Matondong, A.(2019). Dampak Modernisasi Terhadap Kehidupan Sosial Masyarakat. Jurnal Wahana Inovasi, 8(2), 189-192.

Porda, H., Anis, M., Mansyur, M., \& HERI, S. (2013). DARI DISTRIK KE KOTA KECAMATAN Menyusuri Jejak Kota Satui Dalam Lintasan Sejarah.

Rosana, E.(2015). Modernisasi Dalam Perspektif Perubahan Sosial. Jurnal Al-Adyan, 10(1), 189-192.

Soerjono, Sekanto, dan Budi Sulistiyowati. 2015. SOSIOLOGI SUATU PENGANTAR. PT RajaGrafindo Persada Jakarta. 